\title{
Verifying Tourism-Led Growth Hypothesis (TLGH) in Ethiopia: Time Series Analysis
}

\author{
Kidanemariam Gidey Gebrehiwot \\ Ethiopian Civil Service University; College of Finance, Management and Development; department of \\ development Economics and Management
}

\begin{abstract}
Tourism-led growth hypothesis argues that international tourism is a source of economic advancement through generating foreign currency, creating employment opportunities, stimulating greater investments in infrastructure and inspiring the development of other economic sectors that ultimately improved the living standard of the citizens of a country. Knowing the importance of tourism sector, Ethiopia has taken this sector as a strategy to achieve its short and long run economic objectives. Therefore, the principal objective of this study is to validate the Tourism-Led growth hypothesis (TLGH) in Ethiopia over the annual period 1991-2018. To attain the envisaged objective, the standard Augmented Dickey-Fuller (ADF) and Phillips-Perron (PP) unit root tests were applied to check the stationarity of each series. To scrutinize the long run relationship between tourism and economic growth, ARDL bound test of cointegration was applied. In addition, pairwise Granger causality test was used to identify the direction of causality between tourism receipt and economic growth. The empirical findings confirm the existence of long run relationship between tourism receipt, economic growth and other control variables. The results of the pairwise Granger causality also predicted unidirectional causality running from tourism receipt to economic growth in long run. This validates the tourism-led growth hypothesis for Ethiopia. Hence, policy makers should focus on promoting and development of the untapped tourism industry of the country to augment economic growth in Ethiopia.
\end{abstract}

Keywords: Tourism, economic growth, cointegration, pairwise causality

DOI: $10.7176 / \mathrm{JTHS} / 45-01$

Publication date: December $31^{\text {st }} 2019$

\section{Introduction}

Tourism-led growth hypothesis (TLGH) assumes that the development of international tourism boosts economic growth. Similar to the export-led growth hypothesis (ELGH), it advocates that economic advancement can be promoted not only by increasing human resources and technology within the economy, but also by intensifying foreign exchange earnings (Ohlan, 2017). Consequently, different scholars have tried to analyze the effect of tourism on growth and development process of a given economy. Ekanayake and Long (2012) argued that tourism is vital for economic advancement, employment generation and thereby poverty reduction. In addition to providing direct employment creation in the hotel and restaurant industries, it also creates employment in other sectors through its externality on other sector such as agriculture, manufacturing, and food processing and also service sectors such as banking, foreign exchange transactions, transportation, communication (Kammas and SalehiEsfahani, 1992). It can also improve the current account balance through generating foreign currency (Oh, 2005). International tourism directly inspires the development of local industries such as transport, hotels and restaurants, manufacturing, handicraft, agriculture and the trade (Lionetti and Gonzalez, 2012). Besides, Khalil, Kakar, and Malik (2007) argued that tourism industry can boost household's income and government revenues through multiplier effects.

However, many authors questioned the favorable effect of international tourism on economic growth as there might be leakages as well. According to Kammas and Salehi-Esfahani (1992), "imported goods that are demanded by the tourists, and the cost of goods and services that are needed for the infrastructural development of the industry" are the leakages. In addition, the expansion of the tourism infrastructure such as construction of hotels could cause the pollution of coastal waters, especially if sewerage capacity is inadequate (Sunlu, 2003). As a result, tourism expansion may adversely affect the economy. Therefore, it is important to conduct more vigorous research so as to evaluate the net effect of tourism industry on a given economy.

Even though the empirical findings have no clear-cut answer for the effect of tourism on economic growth, many countries give attention international tourism as a strategy to achieve their short and long run economic objectives. Ethiopia is one of the countries that used it as its development strategy. In Ethiopia, the perception about the importance of tourism industry is traced back to the early 1960s. Ethiopia has been working to revitalize the nation's tourism industry through restructuring the responsible organizations and introducing new systems (Ministry of Culture and Tourism, 2019). According to the United Nations World Tourism Organization report and Ministry of tourism and culture reports, the number of international tourists and tourism receipts in Ethiopia is gradually increasing from time to time. Therefore, the main objective of the study is to analyze the effect of tourism on economic growth in Ethiopia over the period 1991-2018. That means, this paper tests the validity of 
tourism-led growth hypothesis for Ethiopia.

The remaining part of the paper is organized as follows: Section-two briefly reviews theoretical and empirical literature. Section-three deals with research methodology and model specification. Section-four consists of the result and discussion part of the paper. The last section deals with brief conclusion and recommendation.

\section{Literature Review}

\subsection{Theoretical literature}

According to the Tourism-led growth hypothesis (TLGH), international tourism is a source of economic growth for many countries through its contribution to foreign exchange revenues for government and stimulating greater investments in infrastructure that ultimately improve the living standard of the citizens of a country (Balaguer \& Cantavella-J, 2002 ; UNWTo, 2017 and Risso \& Bonapace, 2009). There are four major mechanisms through which tourism industry can positively affect economic growth. First, like export, tourism generates foreign currency required to finance imports of investment and intermediate goods used to add value in the production process. Second, tourism industry inspires investments in physical infrastructure and in human capital like education (Brida , Cortes-Jimenez and Pulina ,2016). Third, the spending of international tourism can inspire the development of other industries such as transport, hotels and restaurants, manufacturing, handicraft, agriculture and the trade (Lee, 2012 and Lionetti and Gonzalez, 2012 and Brida, Cortes-Jimenez and Pulina ,2016). Fourth, it can directly or indirectly generate employment that activate consumption and investment among local economic agents (Kammas and Salehi-Esfahani, 1992, Ekanayake and Long, 2012 and Brida, Cortes-Jimenez and Pulina ,2016).

\subsection{Empirical Literature}

Numerous empirical studies have been steered on the association between international tourism and economic growth. But their empirical findings are mixed. For instance, Balaguer and Cantavella-Jorda (2002) studied the effect of tourism on economic growth in Spain by using quarterly time series data from 1975-1997. They employed Johansen cointegration and Granger causality test to validate the connection between tourism and economic growth. Their findings showed that there is a long run relationship between tourism and economic growth and the causality runs from tourism to economic growth. Similarly, Grillon (2013) analyzed the dynamics between international tourism and economic growth in Dominican economy during the period 1991-2012. He employed ARDL bounds test to co-integration proposes by Pesaran et al. (2001) and the results confirmed the existence of a long-run equilibrium relationship between tourist arrivals and overall economic growth. Besides, the granger pairwise causality tests show causality running from tourist arrivals to aggregate output expansion. Moreover, Ohlan, (2017) studied the link between tourism and economic growth in India by over the period of 1960-2014. To investigate the relationship between the two variables he used the newly-developed Bayer and Hanck combined cointegration test and the result indicated that tourism and economic growth are cointegrated. In addition, the Granger-causation test indicated the tourism leads economic growth. Shih and Do (2016) also found a favorable impact of tourism on economic growth over the period of 1995-2013 by using a Granger causality test and Rolling Window regression method. The findings revealed that tourism has played a key role in driving economic growth in Vietnam economy.

On the other hand, Ekanayake \& Long (2012) applied heterogeneous panel cointegration technique to examine the effect of tourism sector on economic growth in developing countries. But their finding showed that the elasticity of tourism revenue with respect to economic growth is positive but not statistically significant in developing countries fails to support. Their granger causality test also fails to support tourism-led growth hypothesis. This finding is supported by Chou (2013). He found a neutral relationship between tourism development and economic growth for Bulgaria, Romania and Slovenia. Similarly, Oh (2005) said that there is no long-run association between tourism and economic growth in South Korea, and he found a uni-directional causality running from economic growth to tourism development. Another research done by Payne and Mervan, (2010) in Croatia by applying Toda-Yamamoto long-run causality test over the period 2000-2008 did not confirm the existence of tourism-led growth hypothesis. Their empirical finding reveals a positive unidirectional causality that runs from real GDP to international tourism receipt which support for the economic-driven tourism growth hypothesis rather than tourism driven economic growth hypothesis. Chou (2013) also found a significant and negative impact of tourism spending on economic growth in Estonia and Hungary. According to Chou, the detrimental effect of tourism on economic growth is resulted in due to an increase in the relative price of nontraded goods which lowers the demand for the capital used in the traded sector.

\section{Methodology of the study}

\subsection{Data Source and variable description}

This study used 28-year annual data from 1991-2018E.C. The dependent variable is per capita real GDP which is used as a proxy for economic growth while the explanatory variables are tourism receipt to export ratio, real gross 
capital formation, and gross enrollment. The variables nominated in the study are based on the tourism-led growth hypothesis which posits that international tourism boosts economic growth through intensifying foreign exchange earnings, creating employment opportunity and positive externality (Ohlan,2017). The inclusion of other control variables (gross capital formation-proxy for physical capital formation and gross enrollment rate -proxy for human capital) in the analysis is to reduces the omitted variable bias. In addition, as the dependence of Ethiopian Economy on Agriculture is very high, drought dummy which captures the recurrent drought is included in the model. The dynamics of leadership change may have an economic implication on a given country (Carbone \& Pellegata, 2018). Therefor to capture the effect of leadership change on economic growth, leadership change dummy is added to in to the model. International tourism receipt is measured as a ratio of total export while government spending and remittance are measured as a percentage of GDP. Some of the variables included in the model were obtained from international official data sources (world development indicator and UN-stats) while the remaining variables were obtained from domestic sources (from ministry of culture and tourism and ministry of education).

\subsection{The Model}

In order to verify the tourism-led growth hypothesis, the standard classical production function is used. Because it is the most widely used aggregate production function in macroeconomics analysis. For instances, Balaguer and Cantavella-Jordà (2002) have followed this functional form in order to prove the link between tourism and economic growth. In addition to the standard production inputs (human and physical capital) tourism was included in the model as non-standard type of export. Therefore, my research followed the following modified production function:

$\mathrm{PCGDPg}_{t}=0+1 \mathrm{TOUR}_{t}+\quad \mathrm{RGCFg}_{t}+$ ENROLg $_{t} \quad$ DROUT $+\quad L E D C H+U_{t}$

Where: $\mathrm{PCGDPg}_{t}=$ Per capita real GDP growth rate at time $t$.

TOUR $_{t}=$ Tourism receipt as a percentage of total export at time $t$

$\mathrm{RGFCg}_{t}=$ Real gross fixed capital growth rate at time $t$.

ENROLg $_{t}=$ Growth rate of secondary school gross enrolment at time $t$.

DROUT $=$ Dummy variable for recurrent drought

$\mathrm{LEDCH}=$ Dummy variable for leadership change

$e_{t}=$ Random variable at time $t$.

$\mathrm{U}_{t}=$ error term

\subsection{Method of Analysis}

\subsubsection{Stationarity test}

Most time series data exhibit a non-stationary pattern in their levels. So, in order to determine the degree of stationarity, a unit root testing was carried out through the Augmented Dicky-Fuller (ADF) test and Philips-Perron (PP) test.

\subsubsection{Cointegration test}

In order to test the existence of a stationary equilibrium relationship among the variables of interest, the univariate cointegration approaches of Engle and Granger (1987) and Phillips and Hansen (1990), and the multivariate cointegration procedures of Johansen and Juselius (1990), have been used extensively in the literature. Recently, the cointegration approach by Pesaran et al. (2001), known as the ARDL bounds testing, has become popular among researchers. In this research, ARDL approach to cointegration is used to prove the existence of long run and short-run relationship among the variables of interest. This approach has several advantages over other cointegration techniques (Pesaran et al., 2001). First, it is applicable irrespective of whether the underlying regressors are purely I (0), purely I (1) or fractionally integrated. Second, the model uses a sufficient number of lags to capture the data-generating process in general to the specific modelling framework. Third, the error correction model is derivable from the ARDL through a simple linear combination, which integrates both shortrun adjustments with long-run information without losing the latter's information. Fourth, the small samples properties of the ARDL procedure are far superior to those of the multivariate cointegration techniques. Fifth, endogeneity and serial correlation problems are corrected through appropriate lag selection. (Umoh and Effiong, 2013). Therefore, this study applied Autoregressive Distributed Lag (ARDL) Model to analyzing the long run and short run effects of tourism receipt on economic growth in Ethiopia. To test whether there is a long run equilibrium relationship between the variables; bounds test for co-integration is carried out as proposed by Pesaran, Shin, and Smith (2001). Accordingly, the hypothesis of the relationship between tourism receipt and economic growth is tested based on the following ARDL bound test equation.

$$
\begin{aligned}
& \Delta \text { PCGDP }_{\mathrm{gt}}=\beta_{\mathrm{o}}+\lambda_{1} \text { PCGDP }_{\mathrm{gt}-\mathrm{i}}+\lambda_{2} \text { LnTOUR }_{\mathrm{t}-\mathrm{i}}+\lambda_{3} \text { RGCF }_{\mathrm{gt}-\mathrm{i}}++\lambda_{4} \text { ENROL }_{\mathrm{gt}-\mathrm{i}} \\
& +\beta_{1} \sum_{\mathrm{i}=1}^{\mathrm{n}} \Delta \text { PCGDP }_{\mathrm{g}-\mathrm{i}}+\beta_{2} \sum_{\mathrm{i}=0}^{\mathrm{n}} \Delta \mathrm{TOUR}_{\mathrm{t}-\mathrm{i}}+\beta_{3} \sum_{\mathrm{i}=0}^{\mathrm{n}} \Delta \text { LnRGCF }_{\mathrm{gt}-\mathrm{i}}++\beta_{4} \sum_{\mathrm{i}=0}^{\Delta \text { ENROL }_{\mathrm{gt}-\mathrm{i}}}
\end{aligned}
$$




$$
\beta_{5} \text { DROUT }_{t}+\beta_{6} \text { DROUT }_{t}+e_{t}
$$

Where: PCGDPg $_{t}=$ Per capita real GDP growth rate at time $t$.

TOUR $_{t}=$ Tourism receipt as a percentage of total export at time $t$

$\mathrm{RGFCg}_{t}=$ Real gross fixed capital growth rate at time $t$.

ENROLg $_{t}=$ Growth rate of secondary school gross enrolment at time $t$.

DROUT $=$ Dummy variable for recurrent drought

LEDCH= Dummy variable for leadership change

$e_{t}=$ Random variable at time $t$.

According to Pesaran et al. (2001), if the computed Wald F-statistic is less than the lower bound critical value, there is no long run relationship between the variables included in the model (tourism receipt and economic growth and other control variables). That means, the null hypothesis $\left(\lambda_{1}=\lambda_{2}=\lambda_{3}=\lambda_{4}=0\right.$. $)$ will not be rejected. On the other hand, if the calculated F-statistic is greater than the upper bound critical value, then there is a long run relationship between tourism receipt and economic growth accepted. That means, alternative hypothesis of long run relationship $\left(\lambda_{1} \neq \lambda_{2} \neq \lambda_{3} \neq \lambda_{4} \neq 0\right.$. $)$ will be accepted.

Further, pairwise Granger causality test is applied to determine whether there is uni-directional causality or bi-directional causality between tourism receipt and economic growth in Ethiopia.

\section{Overview of Tourism sector in Ethiopia}

In Ethiopia, the perception about the importance of tourism industry is traced back to the early 1960s. Ethiopia has been working to revitalize the nation's tourism industry through restructuring the responsible organizations and introducing new systems (Ministry of Culture and Tourism, 2019). As clearly indicated in Figure-1, the number of international tourists has gradually increased over the past twenty-seven years. In 1991 the number of international tourists in Ethiopia was about 81581. This figure has continuously increased up to the year 1997 and reached 138856. In the next two consecutive it has recorded a poor performance. This could be due to the war between Ethiopia and Eritrea which took place from 1998 to 2000. After the year 2000, the total no of tourists arrived in Ethiopia has continued to grow until 2017. In comparison to the growth registered in previous years, the increment in tourism number in 2016 was insignificant. This slowdown in visitor arrivals in 2016 was due to the violent anti-government protests across the country started at the end of 2015 which led the Ethiopian government to pronounce a six-month state of emergency. Countries which are the major source of Ethiopian tourism market (United States, United Kingdom, Germany and others) cautioned their citizens not to travel to some regions of Ethiopia. This phenomenon adversely affected Ethiopia's holiday tourism sector as many international operators cancelled planned trips (Altes,2018). Then the figure of visitor arrivals has reimbursed to progress in 2017. However, the number of visitors again declined in 2018.

Similar to the trend of visitor arrival, the gross revenue generated by the tourism sector (tourism receipt) has recorded a continuous progress (except for the year 1998 and 1999) over the past twenty-seven years. However, the progress in tourism receipt showed a big jump since 2013. This structural break was happened due to the update of parameters used to calculate tourism revenue (Tourism Statistics bulletin, 2009-2015). This shows that tourism sector could be one potential sector of foreign currency generation (see Figure-2 for detail).

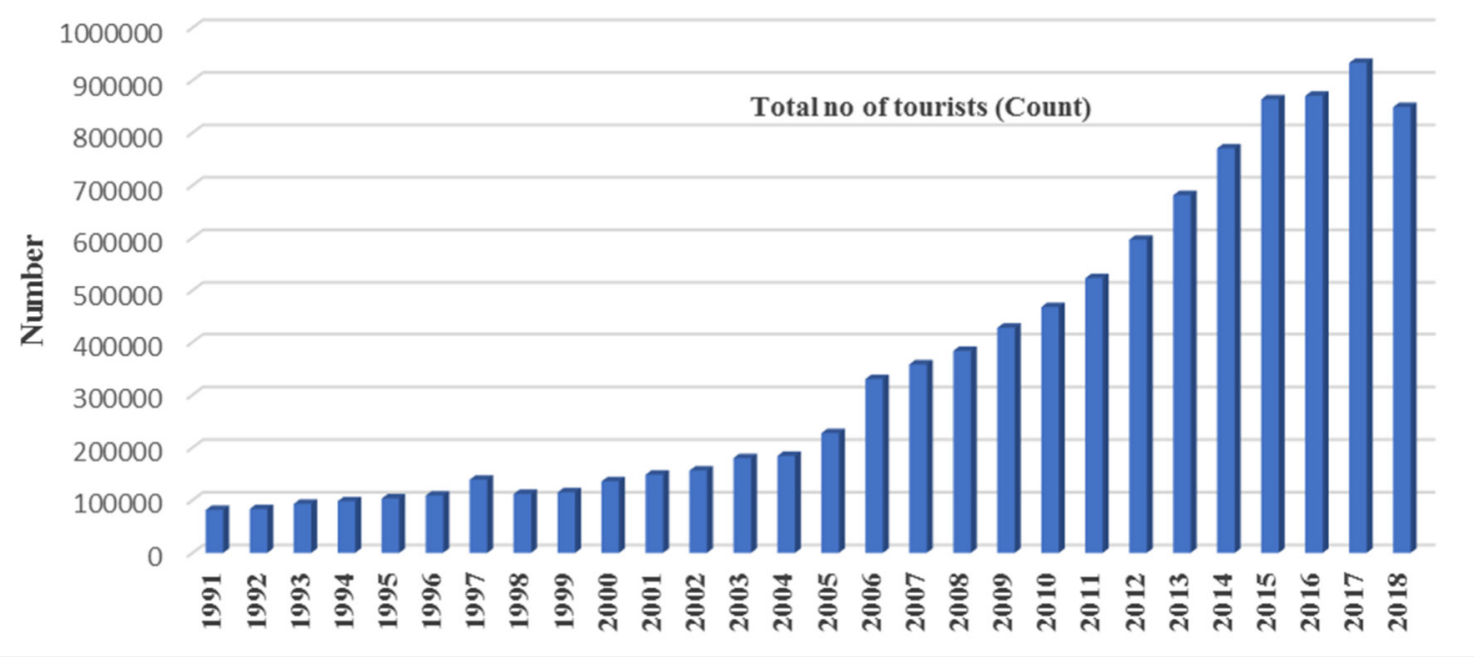

Figure1: Total number of tourists (1991-2018)

Source: Own computation, 2019 


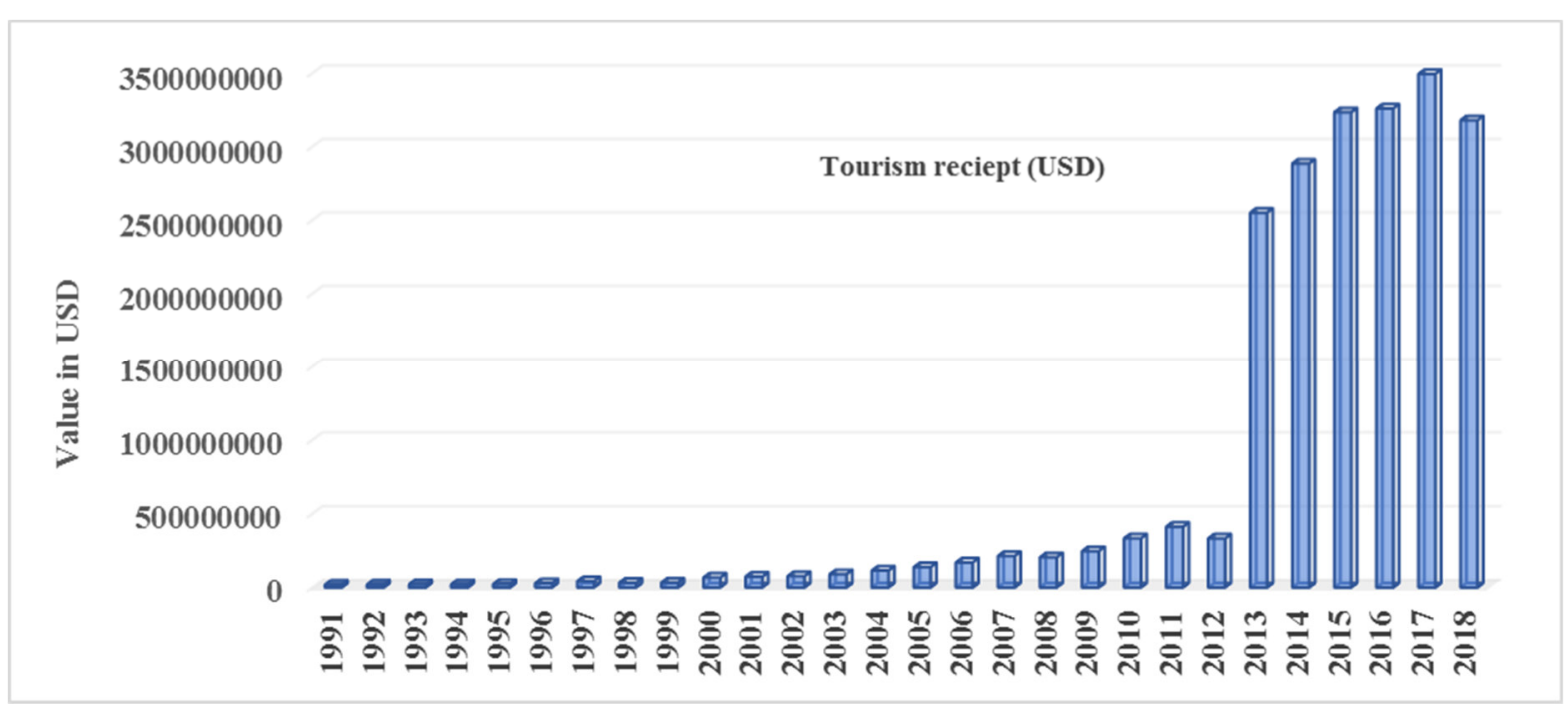

Figure 2: Tourism receipt (in USD)

Source: Own computation, 2019

As clearly reported in Figure-3 below, travel for leisure and holiday is the main reason tourists flow to Ethiopia. When we see the purpose of visits as of 2018 , more than one third $(37.2 \%)$ of the tourists travel to Ethiopia for leisure and holiday purpose. Transit and business tourism have also a considerable share in Ethiopian tourism sector which accounts $20.1 \%$ and $15.8 \%$ respectively.

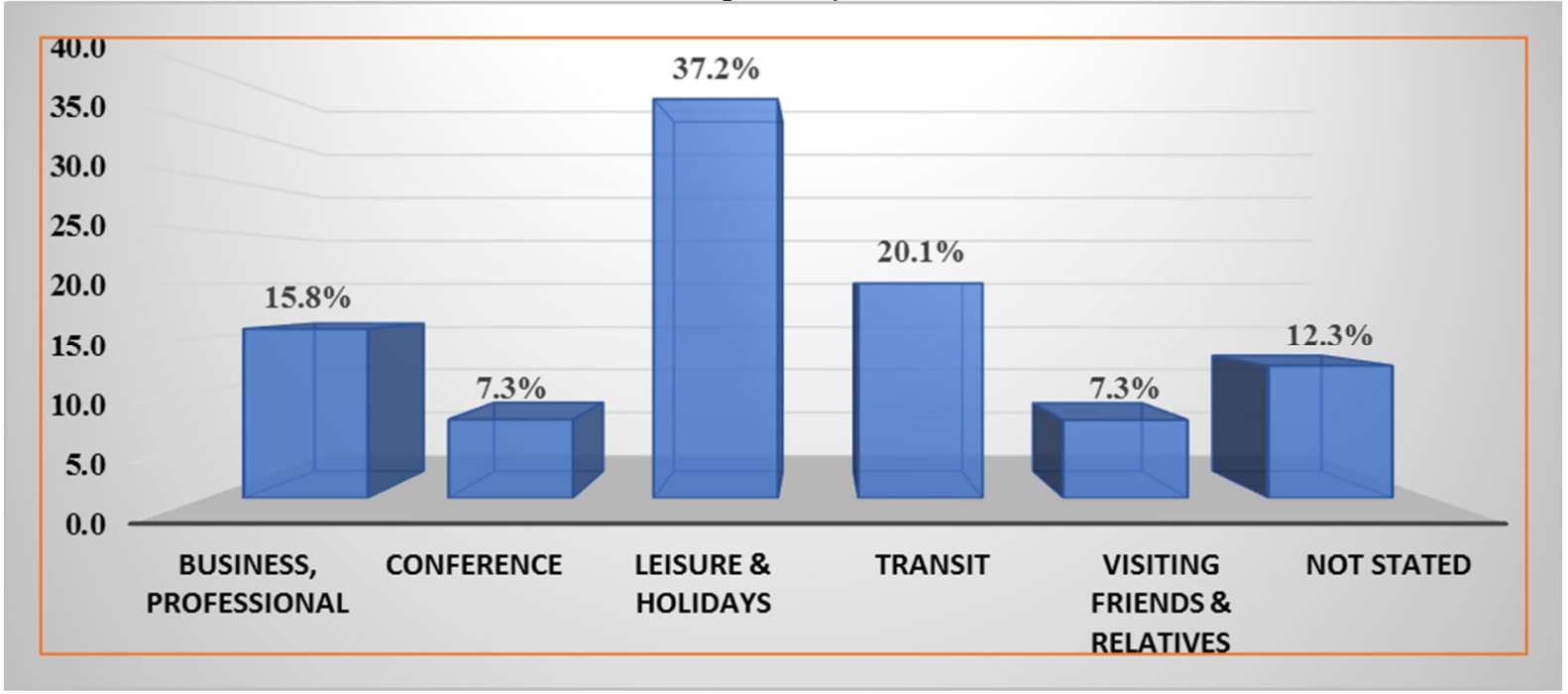

Figure3: Purpose of visit (2018)

Source: Own computation, 2019

Most of the tourists who visit Ethiopia in 2018 came from Africa (30\%), Europe (29\%) and Americas (21\%). Specifically, most of the African tourists came from Nigeria, Kenyan, Sudan, South Africa and Djibouti. When we see the specific origin of the European tourists who visit Ethiopia in 2018 are from United Kingdom, Germany, Italy, France and Sweden. 


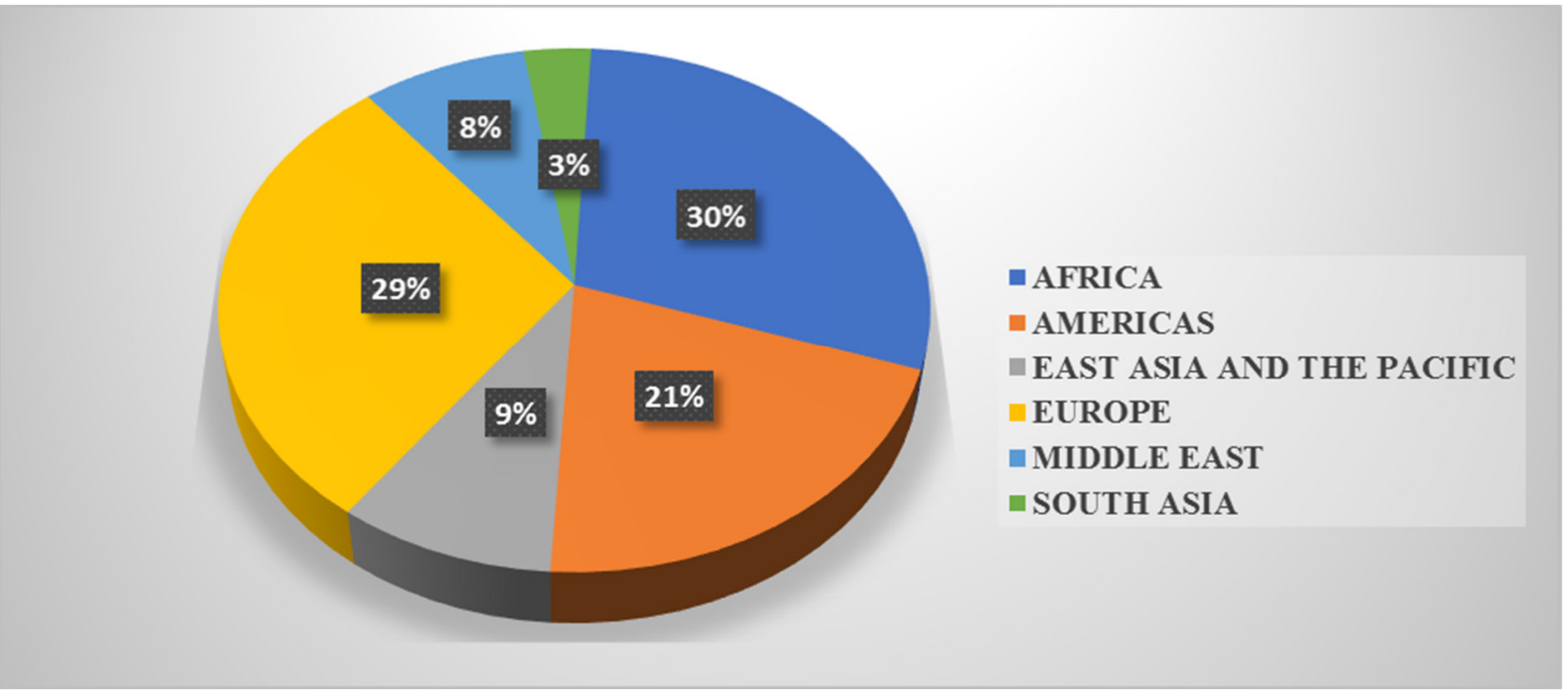

Figure 4: Tourist arrival by continents/regions (2018)

Source: Own computation, 2019

The top ten sources of tourism market to Ethiopia in 2018 are reported in Figure- 5 below. The reported figures indicate that USA is the major sources of visitors to Ethiopia, accounting $17.4 \%$ of the total visitors. Next to USA, China (about 6\%) and United Kingdom (about 5\%), Germany (about 4\%), Italy (about 3.7\%), France (3.2\%), India (about 3\%), Kenya (2.7\%), Sudan (2.5\%), and Saudi Arabia (2.5\%) are the other major tourism market sources.

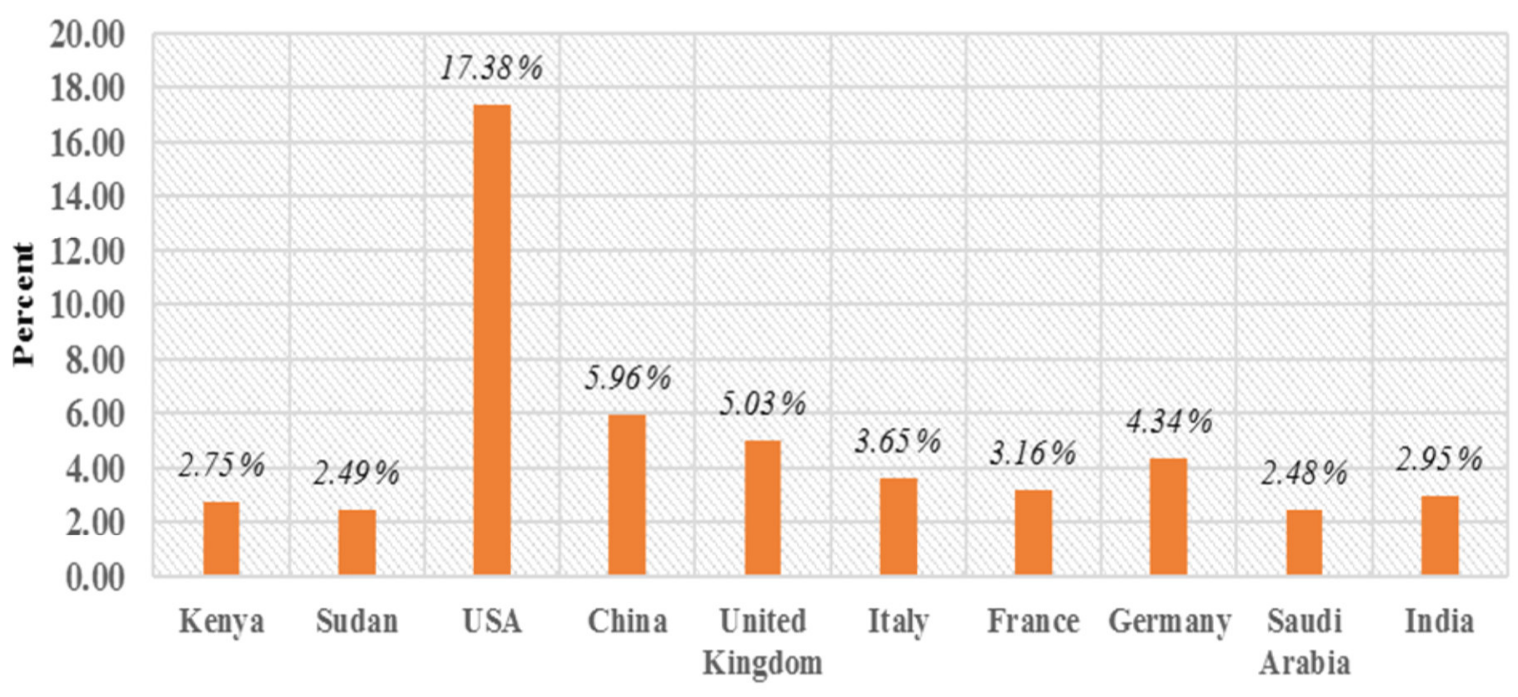

Countries

Figure 5: The top ten major sources of tourism market to Ethiopia (2018)

Source: Own computation, 2019

\section{Results and discussion}

\subsection{Correlation matrix and Descriptive statistics}

In order to have a general picture, the correlation matrix descriptive statistics about each variable over the period 1991-2018 is reported in Table 1. The mean of GDP per capita growth (PCGDPg), Gross Capital Formation growth (RGCFg), tourism receipt as a \% of total export (TOUR) and secondary school enrollment growth (ENROLg) are about $4.14 \%, 13.57 \%, 27.42$ and $7.05 \%$ respectively. Over the period 1991-2018 real GDP per capita recorded a maximum growth of $10.41 \%$ and a minimum growth of $-12.13 \%$. On the other hand, tourism receipt as a\% of total export reached a maximum value of $39.23 \%$ and a minimum value of $15.97 \%$. The descriptive statistics also showed that only real per capita GDP growth is normally distributed with Jarque-Bera statistic of 7.66 and probability value of $0.023<0.05$. As displayed in the correlation matrix, the real GDP per capita, real gross capital 
formation, tourism receipt as a\% of total export and secondary school enrolment are positively correlated. But gross enrollment is negatively correlated with real gross capital formation.

Table 1: Descriptive statistics and correlation matrix

\begin{tabular}{lrrrr}
\hline \hline Variables & PCGDPg & RGCFg & TOUR & ENROLg \\
\hline \hline Descriptive statistics & & & & 7.054133 \\
\hline \hline Mean & 4.141918 & 13.57019 & 27.42179 & 5.801182 \\
Median & 6.708212 & 13.47193 & 27.41000 & 28.76501 \\
Maximum & 10.40825 & 53.96966 & 39.23000 & -12.97040 \\
Minimum & -12.12915 & -27.60150 & 15.97000 & 9.995834 \\
Std. Dev. & 6.296404 & 21.66090 & 7.267754 & 0.046989 \\
Skewness & -1.248266 & -0.071825 & 0.019662 & 3.013330 \\
Kurtosis & 3.574354 & 2.434140 & 1.683516 & 0.010511 \\
Jarque-Bera & 7.656314 & 0.397639 & 2.023790 & 0.994758 \\
Probability & 0.021750 & 0.819698 & & \\
\hline Correlation matrix & & & & \\
\hline \hline PCGDPg & 1.000000 & & & 1.000000 \\
RGCFg & 0.589833 & 1.000000 & 1.000000 & \\
TOUR & 0.600094 & 0.300875 & 0.249450 & \\
ENROLg & 0.150382 & -0.215982 & & \\
\hline \hline
\end{tabular}

Source: Author computation, 2019

\subsection{Unit Root Test and Optimum lag selection}

Before testing the long-run and short run association between the variables it is compulsory to examine the integrating properties of the variables. To do this, the standard Augmented Dickey-Fuller (ADF) and PhillipsPerron(PP) unit root tests were applied. Trend and intercepts are included in the tests. The results of the ADF test reported in Table-2 confirmed that PCGDPg and RGCFg are not subject to unit root problem at level with intercept at $1 \%$ level of significance. On the other hands TOUR and ENROLg are not stationary at level. This clearly shows that the integrating order of the variables is not unique rather a mixture of I (1) and I (0). The robustness of ADF unit root test is checked by applying PP unit root test. Accordingly, the results provided by ADF test are reliable and consistent. That means the PP unit root test validates that variables are a mixture of I (1) \& I (0).

In order to determine the appropriate lag order, VAR lag order selection criteria was used. We have followed Schwarz information criterion (SIC) for choosing appropriate lag length due to its superior properties (Pesaran and Smith, 1998 and Liew, et.al. 2008). It has considerable high performance in selecting the true lag order, even if the sample size is small. The results reported in the Table-3 reflect that lag 1 is suitable for the sample size.

Table 2: Unit Root Analysis

\begin{tabular}{lllllll}
\hline & \multicolumn{3}{c}{ ADF Unit Root Test } & \multicolumn{2}{c}{ PP Unit Root Test } \\
\cline { 2 - 6 } Variables & T-statistic & Prob.Values & Decision & T-statistic & Prob.Values & Decision \\
\hline \hline PCGDPg & -4.766992 & $0.0038^{*} *$ & Stationary & -5.086785 & $0.0018^{* *}$ & Stationary \\
TOUR & -2.704333 & 0.2426 & Non-stationary & -2.730775 & 0.2330 & Non-stationary \\
RGCFg & -6.834482 & $0.0000^{*}$ & Stationary & -7.121911 & $0.0000^{*}$ & Non-stationary \\
ENROLg & -3.498830 & 0.0597 & Non-Stationary & -3.362228 & 0.0779 & Non-Stationary \\
\hline \hline$\Delta$ PCGDPg & -7.537269 & $0.0000^{*}$ & Stationary & -15.60970 & $0.0000^{*}$ & Stationary \\
$\Delta$ TOUR & -6.367981 & $0.0001^{*}$ & Stationary & -6.367981 & $0.0001 *$ & Stationary \\
$\Delta$ RGCFg & -5.770887 & $0.0005^{*}$ & Stationary & -30.11607 & $0.0000^{*}$ & Stationary \\
$\Delta$ ENROLg & -6.401516 & $0.0001^{*}$ & Stationary & -12.73066 & $0.0000^{*}$ & Stationary \\
\hline \hline
\end{tabular}

Source: Author computation, 2019

Note: Significance at $1 \%$ and $5 \%$ is shown by *and **respectively.

Table 3: Optimum lag of the model

\begin{tabular}{llll}
\hline \hline Number of lags & AIC & SIC & HQIC \\
\hline \hline Lag 0 & 28.00844 & 28.20346 & 28.06253 \\
Lag 1 & $26.47437^{*}$ & $27.44947^{*}$ & $26.74482^{*}$ \\
Lag 2 & 26.63598 & 28.39116 & 27.12280 \\
Lag 3 & 27.24141 & 29.77667 & 27.94458 \\
\hline \hline
\end{tabular}

Source: Author computation, 2019

Note: AIC = Akaike info criterion, $S I C=$ Schwarz info criterion \& HQIC=Hanan-Quinn info criterion. The lower the value of each criterion the best the model is in that lag order. 


\subsection{Cointegration results}

After checking the unit root properties and identifying the appropriate lag length of the variables, the bounds test of cointegration is conducted in order to analyze the long-run relationship between the variables. Table 4 presents the calculated F-statistics and critical values for bound test. As can be seen from the table the calculated F-statistic $=5.895$ and is greater than the upper bound critical value of 6.36 provided by Pesaran et al. (2001) at the $2.5 \%$ level of significance. Accordingly, the null hypothesis of no long-run relationship is rejected. Therefore, the conclusion is that there is cointegration or a long-run relationship between RGDPg, TOUR, and the other control variable included in the model.

Table 4: ARDL Bounds Test

Sample: 1992-2018

Included observations: 27

\begin{tabular}{|c|c|c|}
\hline $\begin{array}{l}\text { Test Statistic } \\
\text { F-statistic } \\
\text { Critical Value Bounds }\end{array}$ & $\begin{array}{l}\text { Value } \\
5.895152\end{array}$ & $\begin{array}{l}\mathrm{k} \\
3\end{array}$ \\
\hline Significance & I0 Bound & I1 Bound \\
\hline $10 \%$ & 3.47 & 4.45 \\
\hline $5 \%$ & 4.01 & 5.07 \\
\hline $2.5 \%$ & 4.52 & 5.62 \\
\hline $1 \%$ & 5.17 & 6.36 \\
\hline
\end{tabular}

Source: Author computation, 2019

After confirming the existence of a long-run relationship between the four variables included in the growth model, the long-run equation is estimated. Table 5 presents the results of the estimated long-run coefficients of the estimated growth model. The coefficients of all of the variables included in the model (except ENROg) are statistically significant at $1 \%$. Tourism receipt to export ratio (TOUR) and growth in gross capital formation (RGCFg) positively and significantly affects economic growth at $1 \%$ and $5 \%$ respectively. As expected, the recurrent drought dummy variable (DROU) and leadership change dummy (LEDCH) negatively and significantly affects real per capita GDP growth at $1 \%$ level of significance. The coefficient of tourism receipt to export ratio (TOUR) is about 0.964 , suggesting that as the ratio of tourism receipt to export increases by 1 percent, economic growth will increase by about 0.964 percent per year. This finding is consistent with the argument of tourism-led growth hypothesis (TLGH) which argued that international tourism is a source of economic growth through its contribution to foreign exchange revenues, stimulating greater investments in infrastructure, and creating employment opportunities that ultimately improve the living standard of the citizens of a country (Balaguer \& Cantavella-J, 2002 ; UNWTo, 2017 and Risso \& Bonapace, 2009). Since tourism is part of the current account balance, it can improve the persistent current deficit in Ethiopia and promote economic growth, if the current marketing and promotion strategy is further improved.

Table 5: Long Run Coefficients: ARDL $(1,0,0,0)$

Sample: 1991- 2018

Included observations: 27

\begin{tabular}{ccccc}
\hline \hline & & & \multicolumn{2}{c}{ Dependent Variable: PCGDPg } \\
\hline \hline Variable & Coefficient & Std. Error & t-Statistic & Prob. \\
\hline TOUR & 0.963757 & 0.297680 & 3.237558 & 0.0043 \\
RGCFg & 0.142522 & 0.039883 & 3.573550 & 0.0020 \\
ENROLg & 0.026372 & 0.117502 & 0.224441 & 0.8248 \\
DROUT & -6.226505 & 2.492930 & -2.497666 & 0.0218 \\
LEDCH & -6.771991 & 3.136158 & -2.159327 & 0.0438 \\
C & -15.442306 & 4.563227 & -3.384076 & 0.0031 \\
@TREND & -0.413604 & 0.232217 & -1.781105 & 0.0909
\end{tabular}

Source: Author computation, 2019

\subsection{Short run dynamics and ECM}

The error-correction model presented in Table 6 shows that the one period lagged error-correction term is within acceptable levels. As expected, its magnitude is less than one and has a negative sign. Specifically, the coefficient of ECT which measures the speed of adjustment is about -0.895 and is statistically significant at $1 \%$. This implies that approximately $89.5 \%$ of shocks from the previous period are corrected within the current year. This result implies that economic growth converges to its long-run equilibrium by $89.5 \%$ in one year with the speed of adjustment via the channel of tourism receipt and other control variables. As clearly indicated in Table 6, the short run effect of the explanatory variables is similar to the long run effect. The results show that tourism has a statistically significant positive impact on economic growth. This signifies that tourism acts as an engine of 
economic growth in the short-short-run as well.

Table 6: Short run coefficients: ARDL $(1,0,0,0)$

Sample: 1991-2018

Included observations: 27

\begin{tabular}{lrrrc}
\hline \hline \multicolumn{4}{c}{ Dependent Variable: $\Delta$ PCGDPg } \\
\hline \hline Variable & Coefficient & Std. Error & t-Statistic & Prob. \\
\hline \hline$\Delta$ TOUR & 0.862899 & 0.209997 & 4.109100 & 0.0006 \\
$\Delta$ RGCFg & 0.127607 & 0.038490 & 3.315364 & 0.0036 \\
$\Delta$ ENROLg & 0.023612 & 0.107808 & 0.219022 & 0.8290 \\
DROUT & -5.574895 & 1.950202 & -2.858624 & 0.0101 \\
LEDCH & -6.063296 & 2.186962 & -2.772475 & 0.0121 \\
@TREND & -0.370320 & 0.184390 & -2.008348 & 0.0590 \\
ECT (-1) & -0.895349 & 0.183574 & -4.877316 & 0.0001 \\
\hline \hline
\end{tabular}

Source: Author computation, 2019

\subsection{Diagnostic test}

The soundness of the results is dependent on the fit and stability of the model. Therefore table 7 summarizes the results of the various diagnostic and stability tests of the TLGH model. Based on the Breusch-Godfrey serial correlation LM Test, there is no serial correlation in the model. AS proved by the Jarque- Bera normality test, the residuals are normally distributed in the model. The model also appears not be heteroscedastic as it passes the Breusch-Pagan-Godfrey heteroskedasticity tests. The Ramsey RESET test results also confirm that the model is correctly specified and stable.

Table 7: Diagnostic test

\begin{tabular}{llcccc}
\hline \hline & \multicolumn{4}{c}{ Types of Tests } \\
\cline { 2 - 6 } F-statistics and P-values & $\chi^{2} S C$ & $\chi^{2} H$ & $\chi^{2} A R C H$ & $\chi^{2} N$ & $\begin{array}{c}\text { Ramsey } \\
\text { Reset Test }\end{array}$ \\
\hline \hline Calculated F-statistics & $\mathbf{0 . 2 8 5 4 1}$ & $\mathbf{1 . 2 5 3 7}$ & $\mathbf{0 . 3 5 7 0 8}$ & $\mathbf{0 . 8 4 5 1}$ & $\mathbf{2 . 8 6 6 4 2}$ \\
P-values & $\mathbf{0 . 7 5 5 2 0}$ & $\mathbf{0 . 3 2 3 8}$ & $\mathbf{0 . 5 5 5 7}$ & $\mathbf{0 . 6 5 5 4}$ & $\mathbf{0 . 0 8 4 6}$ \\
\hline \hline
\end{tabular}

Source: Author computation, 2019

Note: $\quad \chi^{2} \mathrm{SC}=$ Breusch - Godfrey Serial Correlation LM Test,$\chi^{2} \mathrm{H}=$ Breusch-Pagan-Godfrey test for heteroscedasticity, $\chi^{2} \mathrm{ARCH}=\mathrm{ARCH}$ test for heteroscedasticity, $\chi^{2} N=$ Jarque-Bera normality Test. Ramsey Reset test was performed based on the squared fitted values.

Further, the level of multicollinearity is also tested in terms of Variance Inflation Factor (VIF). Accordingly, the VIF (centered) values reported in Table 8 clearly shows that there is no multicollineariy problem.

Table 8: Variance Inflation Factors

Sample: 1991- 2018

Included observations: 27

\begin{tabular}{ccc} 
& Coefficient & Centered \\
Variables & Variance & VIF \\
PCGDPg & 0.033699 & 2.761488 \\
RGCFg & 0.001481 & 1.826089 \\
TOUR & 0.044099 & 7.216206 \\
ENROLg & 0.011623 & 2.513194 \\
DROUT & 3.803288 & 2.710461 \\
LEDCH & 4.782801 & 2.421671 \\
C & 11.65733 & $\mathrm{NA}$ \\
aTREND & 0.034000 & 6.069592 \\
\hline
\end{tabular}

Source: Author computation, 2019

\subsection{Pairwise Granger causality results}

In order to identify the direction of causality between international tourism receipt and economic growth in Ethiopia, pair wise Granger-causality test was conducted. The test result indicated that causality runs from tourism receipt to economic growth. At a lag length of one and two there is a uni-directional Granger causal relationship from tourism receipt to economic growth. This implies that the tourism-Led economic growth hypothesis is valid in Ethiopia. 
Table 9: Pairwise Granger Causality Tests

Sample: 1991- 2018

Lags: 1

\begin{tabular}{lccr}
\hline \hline \multicolumn{1}{c}{ Null Hypothesis: } & Observation & F-Statistic & Prob. \\
\hline \hline TOUR does not Granger Cause PCGDPg & 27 & 6.67277 & 0.0163 \\
PCGDPg does not Granger Cause TOUR & & 0.07455 & 0.7872 \\
Lags: 2 & & & \\
\hline \hline Null Hypothesis: & & & 0.0029 \\
\hline \hline TOUR does not Granger Cause PCGDPg & 26 & 7.84092 & 0.8548 \\
\hline PCGDPg does not Granger Cause TOUR & & 0.15807 & \\
\hline \hline
\end{tabular}

Source: Author computation, 2019

\section{Conclusion and Recommendation}

The main objective of this study was to validate the Tourism-Led growth hypothesis (TLGH) in Ethiopia over the period 1991-2018. The cointegration test result indicates that there is a long run relationship between tourism receipt, economic growth and other control variables. The results of the pairwise Granger causality test also predicted unidirectional causality running from tourism receipt to economic growth. This validates that the tourism-led growth hypothesis works for Ethiopia. This result is consistent with the finding of Cantavella-Jorda (2002) for Spain, Grillon (2013) for Dominican, Ay, Kartal, \& Arslan (2015) for Turkey, Ohlan, (2017) for India, Shih and Do (2016) for Vietnam. Hence, appropriate resources and efforts should be directed towards promoting and developing the untapped tourism industry of the country to augment economic growth. Besides, any intervention related to the sector has to be integrated into the broad national development plan and other universal value chains. In addition, a comprehensive primary survey on the bottlenecks of the sector should be undertaken so as to solve the real challenges of the sector at the grass root level. This enables to further maximize the effect of tourism on the socio-economic development of the country.

\section{REFERENCE}

Altes,C (2018). Analysis of Tourism Value Chain in Ethiopia: Final Report.

Carbone, G. \& Pellegata, A. (2018). Researching the dynamics of leaders' replacement: the Africa Leadership Change (ALC) dataset. European Political Science, 17, 187-210.

Chou, M. (2013). Does tourism development promote economic growth in transition countries? A panel data analysis. Economic Modelling, 33, 226-232.

Ekanayake, E. \& Long, A. (2012). Tourism development and economic growth in developing countries. The International Journal of Business and Finance Research, 6(1), 61-63.

Kmenta, J. (1986). Elements of Econometrics. 2nd ed. New York: Macmillan.

Narayan, P \& Narayan, S. (2007). Is devaluation expansionary or contractionary? Empirical evidence from Fiji. Applied Economics.

Oh, C. (2005). The contribution of Tourism Development to Economic Growth in the Korean economy. Tourism Management, 26(1), 39-44

Ohlan, R. (2017). The relationship between tourism, financial development and economic growth in India. Future Business Journal, 3(1), 9-22.

Payne, J. E. and Mervar, A. (2010). The tourism-growth nexus in Croatia. Tourism Economics, 16(4), 10891094.

Risso, J. \& Bonapace, A. (2009). The contribution of tourism to economic growth: an empirical analysis for the case of Chile. Sustainable Tourism as a Factor of Local Development, 1, 85.

Shih, W.\& Do, N. (2016). Impact of tourism on long-run economic growth of Vietnam. Modern Economy, 7(03), 371.

Sunlu, U. (2003). Environmental impacts of tourism. In Conference on the Relationships between Global Trades and Local Resources in the Mediterranean Region (pp. 263-270).

Kammas, M and Salehi-Esfahani, H. (1992). Tourism and export-led growth: The case of Cyprus, 1976-1988. The Journal of Developing Areas, 26(4), 489-506.

Khalil, S., Kakar, M. K., \& Malik, A. (2007). Role of tourism in economic growth: Empirical evidence from Pakistan economy. The Pakistan Development Review, 985-995.

Balaguer, J., \& Cantavella-Jorda, M. (2002). Tourism as a long-run economic growth factor: the Spanish case. Applied economics, 34(7), 877-884.

UNWTO (2017). Tourism for Development Discussion Paper on the occasion of the International Year of Sustainable Tourism for Development 2017.

Brida, J. G., Cortes-Jimenez, I., \& Pulina, M. (2016). Has the tourism-led growth hypothesis been validated? A 
literature review. Current Issues in Tourism, 19(5), 394-430.

Grullón, S. (2013). Is the tourism-led growth hypothesis valid for the Dominican Republic: results from the bounds test for cointegration and granger causality tests. European Journal of Business and Management, 5(25), 18.

Carbone, G., \& Pellegata, A. (2018). researching the dynamics of leaders' replacement: the Africa Leadership Change (ALC) dataset. European Political Science, 17, 187-210.

Pesaran, H., Shin,Y., \& Smith, R. (2001). Bounds testing approaches to the analysis of level relationships. Journal of Applied Econometrics, 16(3), 1924-1996.

Engle, R. F., \& Granger, C. W. (1987). Co-integration and error correction: representation, estimation, and testing. Econometrica: journal of the Econometric Society, 251-276.

Phillips, P. C., \& Hansen, B. E. (1990). Statistical inference in instrumental variables regression with I (1) processes. The Review of Economic Studies, 57(1), 99-125.

Johansen, S., \& Juselius, K. (1990). Some structural hypotheses in a multivariate cointegration analysis of the purchasing power parity and the uncovered interest parity for UK (No. 90-05).

Umoh, O. J., \& Effiong, E. L. (2013). Trade openness and manufacturing sector performance in Nigeria. Margin: The Journal of Applied Economic Research, 7(2), 147-169.

Lee, C. G. (2012). Tourism, trade, and income: Evidence from Singapore. Anatolia, 23(3), 348-358.

Lionetti, S., \& Gonzalez, O. (2012). On the relationship between tourism and growth in Latin America. Tourism and Hospitality Research, 12(1), 15-24. 